\title{
PREDIKSI MAHASISWA BERPOTENSI DROP OUT DENGAN METODE ITERATIF DICHOTOMISER 3 (ID3)
}

\author{
Dede Irmayanti, Yusuf Muhyidin, Dede Arif Nurjaman \\ Program Studi Teknik Informatika, STT Wastukancana \\ Jl. Cikopak No.53 Sadang Purwakarta \\ de2irmayanti@gmail.com, yusufshikudo20@gmail.com, arif.dearif17@gmail.com
}

\begin{abstract}
Education is the process of searching for knowledge by teaching and learning process during the education period. The high level of student success and the low level of student failure reflects the quality of a college. The large number of students who fail when completing education can be assessed against the grades of tertiary institutions which should be considered as early as possible students potentially fail. One way that can be used is to use classification data mining methods. The method used in this research is Knowledge Discovery in Database (KDD), the data processing using the id3 algorithm and the application used is Orange. The amount of data used in this study were 532 students of STT Wastukancana class of 2013 and 577 students of class of 2017 as material to make predictions with attributes worth IPS semester 1-4 and Total SKS. The calculation results are evaluated using a confusion matrix. This study produces a decision tree that is used to determine students who are dropped out with a root node is IPS4. Actual number of Drop outs, Predicted Drop out of 150 data, Actual Number of Drop outs, Predicted Not as much as 55 data, Actual Number of No, Predicted Drop out of 24 data, and Actual Number of No, Predicted Not to amount to 238 data. The calculation accuracy is $83,1 \%, 86.2 \%$ precision and $73.2 \%$ recall.
\end{abstract}

Keywords - data mining, KDD, drop out, id3, decision tree.

\begin{abstract}
Abstrak - Pendidikan adalah proses mencari ilmu pengetahuan yang didapatkan dalam proses belajar mengajar selama masa pendidikan yang ditempuh. Tingginya tingkat keberhasilan mahasiswa dan rendahnya tingkat kegagalan mahasiswa merupakan cermin kualitas dari suatu perguruan tinggi. Banyaknya jumlah mahasiswa yang gagal dalam menyelesaikan pendidikan dapat berpengaruh terhadap nilai dari perguruan tinggi tersebut sehingga perlu dilakukan pencegahan sedini mungkin dengan melakukan prediksi terhadap mahasiswa yang berpotensi Drop out. Salah satu cara yang dapat digunakan adalah dengan menggunakan metode data mining klasifikasi. Metode yang digunakan pada penelitian ini adalah Knowlede Discovery in Database (KDD), proses pengolahan datanya menggunakan algortima id3 aplikasi yang digunakan adalah Orange. Jumlah data yang digunakan pada penelitian ini sebanyak 476 mahasiswa Sekolah Tinggi Teknologi Wastukancana Purwakarta angkatan tahun 2013 dan 577 mahasiswa angkatan 2017 sebagai bahan untuk melakukan prediksi dengan atribut yang dinilai adalah nilai IPS semester 1-4 dan Total SKS. Hasil perhitungan dievaluasi akurasinya dengan menggunakan confusion matrix. Penelitian ini menghasilkan decision tree yang digunakan untuk menentukan mahasiswa yang berpotensi Drop out dengan node akar adalah IPS4. Jumlah actual Drop out, predicted Drop out sebanyak 150 data, Jumlah actual Drop out, predicted Tidak sebanyak 55 data, Jumlah actual Tidak, predicted Drop out sebanyak 24 data, dan Jumlah actual Tidak, predicted Tidak sebanyak 238 data. Nilai akurasi perhitungannya sebesar $83,1 \%$, presisi $86,2 \%$ dan recall $73,2 \%$.
\end{abstract}

Kata Kunci - data mining, KDD, drop out, id3, decision tree.

\section{PENDAHULUAN}

Perkembangan teknologi informasi memberikan peluang kepada institusi untuk memanfaatkan teknologi berbasis komputer dalam pengolahan data. Seperti halnya dalam dunia Pendidikan, data akademik dapat diolah menjadi informasi yang sangat berguna untuk menentukan kebijakan-kebijakan maupun strategi dalam peningkatan mutu pendidikan. Informasi dan pengetahuan dapat diperoleh melalui proses pencarian pola dengan menggunakan data mining.

Telah banyak dilakukan penelitian mengenai data mining dalam dunia Pendidikan seperti pada penelitian yang dilakukan oleh aprilianto dan yosepta, penelitian ini bertujuan untuk menganalisis pola kelulusan mahasiswa pada sekolah tinggi manajemen informatika dan komputer asia malang dengan menggunakan algoritma id3. Pada penelitian ini disimpulkan bahwa atribut yang paling menentukan adalah nilai indeks prestasi semester (IPS) pada semester 5[1]. Pada penelitian yang dilakukan oleh Hastuti dan Hidayat tentang analisis algoritma decision tree untuk prediksi mahasiswa non aktif dapat disimpulkan bahwa decision tree dapat menghasilkan nilai akurasi yang sangat baik sehingga sangat efektif jika digunakan untuk proses pengambilan keputusan[2].

Sekolah Tinggi Teknologi Wastukancana Purwakarta merupakan salah satu perguruan tinggi swasta di purwakarta yang sukses menarik banyak mahasiswa disetiap periodenya. Namun ada beberapa hal yang tidak seimbang antara masuk dan keluar mahasiswa di Sekolah Tinggi Teknologi Wastukancana. Berdasarkan data yang diperoleh dari hasil wawancara, jumlah mahasiswa Drop out setiap tahunnya cukup banyak. Data 
mahasiswa angkatan tahun 2013-2016 dapat dilihat pada tabel 1 .

Tabel 1 Data Mahasiswa Angkatan Tahun 2013-2016

\begin{tabular}{|c|c|c|c|c|}
\hline Tahun & Terdaftar & Lulus & Aktif & $\begin{array}{c}\text { Drop } \\
\text { Out }\end{array}$ \\
\hline 2013 & 570 & 270 & 42 & 258 \\
\hline 2014 & 552 & 265 & 108 & 179 \\
\hline 2015 & 633 & 267 & 184 & 182 \\
\hline 2016 & 603 & 34 & 413 & 156 \\
\hline
\end{tabular}

Menurut buku panduan akademik Sekolah Tinggi Teknologi Wastukancana tahun 2014, mahasiswa yang masuk ke dalam kategori Drop out (Pemutusan Studi) adalah mahasiswa yang predikat akademiknya $<2,00$ pada akhir semester IV, jumlah sks nya $<44$ dan melewati masa maksimal studi yaitu 10 semester untuk Jenjang Diploma-3, dan mahasiswa yang predikat akademiknya $<2,00$ pada akhir semester VI, jumlah sks nya $<72$ dan melewati masa maksimal studi yaitu 14 semester untuk Jenjang Strata 1[3].

Berdasarkan permasalahan dan hasil dari beberapa penelitian di atas dapat disimpulkan bahwa penggunaan algoritma id3 dapat digunakan untuk menganalisis data sehingga dapat dilakukan prediksi berdasarkan pola yang terbentuk dari proses data mining. Hal ini menjadi dasar penelitian yang akan dilakukan yaitu mengenai prediksi mahasiswa berpotensi drop out di sekolah tinggi teknologi wastukancana

\section{A. Algoritma Iterative Dichotomiser 3 (ID3)}

Algoritma ID3 adalah algoritma pembelajaran pohon keputusan yang sederhana dikembangkan oleh J. Ross Quinlan pada tahun 1993 [4].

Menurut Mcg David, Algoritma ID3 dapat diimplementasikan menggunakan fungsi rekursif ( fungsi yang memanggil dirinya sendiri). Algoritma ID3 berusaha membangun decision tree (pohon keputusan) secara top-down[5]. Karakteristik ID3 dalam membangun pohon keputusan adalah secara top-down dan divide-and-conquer. Top-down artinya pohon keputusan dibangun dari simpul akar ke daun, sementara divide-and-conquer artinya training data secara rekursif dipartisi ke dalam bagian-bagian yang lebih kecil saat pembangunan pohon. adalah:

Langkah kerja algoritma Iterative Dichotomiser 3

1. Pilih atribut sebagai akar

Untuk memilih atribut sebagai akar, didasarkan pada nilai Gain tertinggi dari atribut-atribut yang ada dan perhitungan entropy.

2. Buat cabang untuk masing-masing nilai

3. Bagi kasus dalam cabang

4. Ulangi proses untuk masing-masing cabang sampai semua kasus pada cabang memiliki kelas yang sama.

5. Ekstraksi Rule dari Decision Tree

\section{B. Entropy}

Entropy adalah ukuran dari teori informasi yang dapat mengetahui karakteristik dari impurity dan homogenity dari kumpulan data [6]. Menurut Rokach dan Maimoon, Information gain atau biasa disebut gain info adalah kriteria pemisahan yang menggunakan pengukuran entropy. Untuk mendapatkan information gain dari suatu atribut dibutuhkan entropy keseluruhan kelas atau Entropy(S) [7], secara matematis entropy dirumuskan sebagai berikut [8]:

Dimana:

$$
\operatorname{Entropy}(S)=\sum_{i=1}^{n}-P i * \log _{2} P i
$$

$$
\begin{array}{ll}
\mathrm{S} & \text { : himpunan kasus } \\
\mathrm{n} & \text { : jumlah partisi } \mathrm{S} \\
\mathrm{pi} & \text { : proporsi dari Si terhadap } \mathrm{S}
\end{array}
$$

\section{Information Gain}

Setelah mendapat nilai entropy untuk suatu kumpulan data, maka kita dapat mengukur efektivitas suatu atribut dalam mengklasifikasikan data. Ukuran efektifitas ini disebut information gain. Secara matematis, information gain dari suatu atribut A, dirumuskan sebagai berikut [8]:

$$
\begin{aligned}
\operatorname{Gain}(S, A)= & \operatorname{Entropy}(S) \\
& =\sum_{i=1}^{n} \frac{|s i|}{s} * \operatorname{Entropy}(S i)
\end{aligned}
$$

Dimana:

$$
\begin{array}{ll}
\mathrm{S} & \text { : himpunan kasus } \\
\mathrm{A} & \text { : atribut } \\
\mathrm{V} & \text { : menyatakan suatu nilai yang mungkin } \\
& \text { untuk atribut A } \\
|\mathrm{Si}| & : \text { jumlah kasus pada partisi ke-i } \\
|\mathrm{S}| & \text { : jumlah kasus dalam } \mathrm{S} \\
\text { Entropy }(\mathrm{Si}) & \text { : entropy untuk sampel-sampel yang } \\
& \text { memilki nilai i. }
\end{array}
$$

\section{Confusion Matrix}

Confusion Matrix adalah tools yang digunakan untuk evaluasi model klasifikasi untuk memperkirakan objek yang benar atau salah. Sebuah matrix dari prediksi yang akan dibandingkan dengan kelas yang asli dari inputan atau dengan kata lain berisi informasi nilai actual dan prediksi pada klasifikasi [9].

Contoh confusion matrix dapat dilihat pada tabel 2.

Tabel 2 Confusion Matrix

\begin{tabular}{|l|l|l|}
\hline \multirow{2}{*}{ Classification } & \multicolumn{2}{|c|}{ Predicted class } \\
\cline { 2 - 3 } & Class $=$ Yes & Class $=$ No \\
\hline \multirow{2}{*}{ Class $=$ Yes } & $a($ true positive & $b($ False Negative \\
& $-T P)$ & $-F N)$ \\
\hline \multirow{2}{*}{ Class $=$ No } & $c($ false positive & $d($ true negatif - \\
& $-F P)$ & $T N)$ \\
\hline
\end{tabular}

\section{METODE PENELITIAN}


Menurut Larose, data mining merupakan analisis dari peninjauan kumpulan data untuk menemukan hubungan yang tidak diduga dan meringkas data dengan cara yang berbeda dengan cara yang sebelumnya yang dapat dipahami dan bermanfaat bagi pemilik data [10]. Proses Knowledge Discovery Database (KDD) secara garis besar dapat dijelaskan yaitu sebagai berikut : 1 . Pembersihan Data (Cleaning Data), 2. Transformasi (Transformation), 3. Data mining, 4. Interpretasi/ evaluasi (interpretation/ evalution) [11]. Kerangka penelitian ini dapat dilihat pada gambar 1.

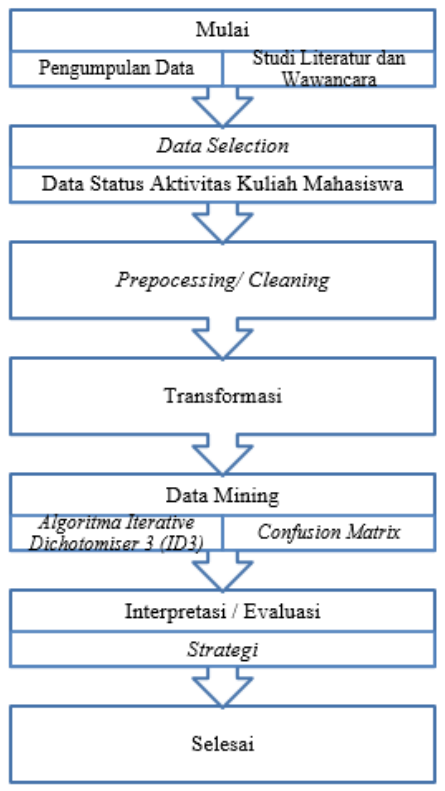

Gambar 1 Kerangka Penelitian

Tahapan proses KDD yang dilakukan pada penelitian ini adalah sebagai berikut:

\section{Data Selection}

Pada tahap ini, penulis melakukan pemilihan (seleksi) data dari sekumpulan data status aktivitas kuliah mahasiswa angkatan 2013 sebanyak 467 orang dan sebanyak 577 data mahasiswa angkatan 2017 sebagai data untuk melakukan prediksi.

2. Preprocessing / cleaning

Pada proses cleaning, penulis membuang atribut data yang tidak diperlukan, duplikasi data, dan memeriksa data yang inkonsisten.

3. Transformation

Data-data yang telah melalui proses selection dan preprocessing tidak bisa langsung digunakan, selanjutnya pada tahap ini dilakukan pembentukan data ke dalam bentuk yang bisa diterapkan untuk proses selanjutnya.

4. Data mining

Pada tahap ini penulis melakukan proses mencari pola atau informasi menarik dalam data terpilih dengan menggunakan algoritma Iteratif Dichotomiser (ID3) dan aplikasi yang digunakan adalah Orange.

5. Interpretation / Evaluation
Pada tahap ini, penulis menganalisis pola-pola yang telah diidentifikasi oleh aplikasi Orange dan kemudian diterjemahkan atau diinterprestasikan ke dalam bentuk yang bisa dimengerti untuk membantu dalam perencanaan strategi bisnis.

\section{HASIL DAN PEMBAHASAN}

\section{A. Pengumpulan Data}

Tahap ini merupakan tahap dimana data yang dibutuhkan dalam penelitian ini dikumpulkan untuk dapat diolah selanjutnya. Data-data yang dikumpulkan adalah data aktifitas kuliah mahasiswa dan data lain yang diperoleh dari informasi dan kutipan, baik dari internet maupun dari literatur yang berkaitan dengan permasalahan yang dihadapi dan diteliti, data yang digunakan merupakan data primer yang dikumpulkan langsung dari proses wawancara di Sekolah Tinggi Teknologi Wastukancana Purwakarta. Sumber data utama yang digunakan dalam penelitian ini adalah dataset aktivitas kuliah mahasiswa angkatan 2013 pada Program Studi yaitu Teknik Informatika, Teknik Industri, dan Teknik Mesin sejumlah 570 record yang terdiri dari dari 264 orang sudah lulus, 42 orang masih aktif kuliah sampai tahun 2020, 1 orang dikeluarkan, 39 orang dengan status hilang, 206 status mengundurkan diri, mutasi sebanyak 17 orang, dan wafat 1 orang. Contoh data awal yang dikumpulkan dapat dilihat pada tabel 3 . 
Tabel 3 Data Awal

\begin{tabular}{|c|c|c|c|c|c|c|c|c|c|c|c|c|c|c|c|c|c|c|}
\hline No & NIM & Nama & Program Studi & $\begin{array}{c}\text { Status } \\
\text { Mahasiswa }\end{array}$ & $\begin{array}{c}\text { Jenis } \\
\text { Pendaftaran }\end{array}$ & $\begin{array}{l}\text { Biaya } \\
\text { Masuk }\end{array}$ & Jenis & $\begin{array}{c}\text { Tempat,Tanggal } \\
\text { Lahir }\end{array}$ & Agama & IPS 1 & SKS1 & IPS2 & SKS2 & IPS3 & SKS3 & IPS4 & SKS4 & Total SKS \\
\hline 1 & 131251001 & $\begin{array}{l}\text { Aa Rahmat } \\
\text { Fauzi }\end{array}$ & $\begin{array}{l}\text { S1 Teknik } \\
\text { Mesin }\end{array}$ & $\begin{array}{l}\text { Mengundurkan } \\
\text { diri }\end{array}$ & $\begin{array}{l}\text { Peserta didik } \\
\text { baru }\end{array}$ & 0 & $\mathrm{~L}$ & $\begin{array}{l}\text { Subang,20-05- } \\
1995\end{array}$ & $\begin{array}{c}\text { Tidak } \\
\text { diisi }\end{array}$ & 0 & 20 & 0 & 0 & 2,6 & 20 & 2,55 & 20 & 60 \\
\hline 2 & 131251002 & $\begin{array}{l}\text { Adi Erwin } \\
\text { Herawan }\end{array}$ & $\begin{array}{l}\text { S1 Teknik } \\
\text { Mesin }\end{array}$ & Mutasi & $\begin{array}{c}\text { Peserta didik } \\
\text { baru }\end{array}$ & 0 & $\mathrm{~L}$ & $\begin{array}{l}\text { Purwakarta,27- } \\
10-1993\end{array}$ & $\begin{array}{c}\text { Tidak } \\
\text { diisi }\end{array}$ & 2,05 & 20 & 2,65 & 20 & 2,1 & 20 & 0 & 0 & 60 \\
\hline 3 & 131251003 & $\begin{array}{l}\text { Agam Gilang } \\
\text { Pamungkas }\end{array}$ & $\begin{array}{l}\text { S1 Teknik } \\
\text { Mesin }\end{array}$ & Lulus & $\begin{array}{c}\text { Peserta didik } \\
\text { baru }\end{array}$ & 0 & $\mathrm{~L}$ & $\begin{array}{l}\text { Purwakarta,31- } \\
08-1995\end{array}$ & $\begin{array}{c}\text { Tidak } \\
\text { diisi }\end{array}$ & 2,75 & 20 & 2,9 & 20 & 3,25 & 20 & 3,25 & 20 & 80 \\
\hline 4 & 131251004 & Alfian Wijaya & $\begin{array}{l}\text { S1 Teknik } \\
\text { Mesin }\end{array}$ & $\begin{array}{c}\text { Mengundurkan } \\
\text { diri }\end{array}$ & $\begin{array}{c}\text { Peserta didik } \\
\text { baru }\end{array}$ & 0 & $\mathrm{~L}$ & $\begin{array}{l}\text { Karawang,26- } \\
12-1994\end{array}$ & $\begin{array}{c}\text { Tidak } \\
\text { diisi }\end{array}$ & 2,65 & 20 & 0 & 0 & 0 & 0 & 0 & 0 & 20 \\
\hline 5 & 131251005 & Angga Anggara & $\begin{array}{l}\text { S1 Teknik } \\
\text { Mesin }\end{array}$ & Mutasi & $\begin{array}{c}\text { Peserta didik } \\
\text { baru }\end{array}$ & 0 & $\mathrm{~L}$ & $\begin{array}{l}\text { Purwakarta,29- } \\
\text { 06-1994 }\end{array}$ & $\begin{array}{c}\text { Tidak } \\
\text { diisi }\end{array}$ & 2,4 & 20 & 2,35 & 20 & 1,95 & 20 & 1,3 & 20 & 80 \\
\hline 6 & 131251006 & $\begin{array}{l}\text { Anton Wahyudi } \\
\text { Irawan }\end{array}$ & $\begin{array}{l}\text { S1 Teknik } \\
\text { Mesin }\end{array}$ & Hilang & $\begin{array}{c}\text { Peserta didik } \\
\text { baru }\end{array}$ & 0 & $\mathrm{~L}$ & $\begin{array}{l}\text { Subang,13-02- } \\
1995\end{array}$ & $\begin{array}{c}\text { Tidak } \\
\text { diisi }\end{array}$ & 2,55 & 20 & 3,25 & 20 & 2,45 & 20 & 1,95 & 20 & 80 \\
\hline 7 & 131251007 & Arif Ramadhani & $\begin{array}{l}\text { S1 Teknik } \\
\text { Mesin }\end{array}$ & Lulus & $\begin{array}{c}\text { Peserta didik } \\
\text { baru }\end{array}$ & 0 & $\mathrm{~L}$ & $\begin{array}{l}\text { Bandung,04-02- } \\
1996\end{array}$ & $\begin{array}{c}\text { Tidak } \\
\text { diisi }\end{array}$ & 3 & 20 & 3 & 20 & 3 & 22 & 3,4 & 20 & 82 \\
\hline 8 & 131251008 & $\begin{array}{l}\text { Bani Ajinudin } \\
\text { Noor }\end{array}$ & $\begin{array}{l}\text { S1 Teknik } \\
\text { Mesin }\end{array}$ & Hilang & $\begin{array}{c}\text { Peserta didik } \\
\text { baru }\end{array}$ & 0 & $\mathrm{~L}$ & $\begin{array}{l}\text { Cirebon,14-12- } \\
1995\end{array}$ & $\begin{array}{c}\text { Tidak } \\
\text { diisi }\end{array}$ & 2,05 & 20 & 1,15 & 20 & 1,8 & 20 & 0 & 0 & 60 \\
\hline 9 & 131251009 & Dede Suardi & $\begin{array}{l}\text { S1 Teknik } \\
\text { Mesin }\end{array}$ & Lulus & $\begin{array}{c}\text { Peserta didik } \\
\text { baru }\end{array}$ & 0 & $\mathrm{~L}$ & $\begin{array}{l}\text { Subang,27-07- } \\
1994\end{array}$ & $\begin{array}{c}\text { Tidak } \\
\text { diisi }\end{array}$ & 2,5 & 20 & 2,95 & 20 & 2,8 & 20 & 3,3 & 20 & 80 \\
\hline 10 & 131251010 & Deni Nugraha & $\begin{array}{l}\text { S1 Teknik } \\
\text { Mesin }\end{array}$ & Lulus & $\begin{array}{l}\text { Peserta didik } \\
\text { baru }\end{array}$ & 0 & $\mathrm{~L}$ & $\begin{array}{l}\text { Purwakarta,08- } \\
02-1995\end{array}$ & $\begin{array}{c}\text { Tidak } \\
\text { diisi }\end{array}$ & 2,9 & 20 & 3,1 & 20 & 3,25 & 20 & 3,4 & 20 & 80 \\
\hline 11 & 131251011 & $\begin{array}{l}\text { Dhiar Eko } \\
\text { Prasetyo }\end{array}$ & $\begin{array}{l}\text { S1 Teknik } \\
\text { Mesin }\end{array}$ & $\begin{array}{c}\text { Mengundurkan } \\
\text { diri }\end{array}$ & $\begin{array}{c}\text { Peserta didik } \\
\text { baru }\end{array}$ & 0 & $\mathrm{~L}$ & $\begin{array}{l}\text { Purwakarta,17- } \\
03-1995\end{array}$ & $\begin{array}{c}\text { Tidak } \\
\text { diisi }\end{array}$ & 3,05 & 20 & 2,85 & 20 & 2,2 & 20 & 3 & 20 & 80 \\
\hline 12 & 131251012 & $\begin{array}{l}\text { Dimas } \\
\text { Ardhiyanto }\end{array}$ & $\begin{array}{l}\text { S1 Teknik } \\
\text { Mesin }\end{array}$ & Lulus & $\begin{array}{c}\text { Peserta didik } \\
\text { baru }\end{array}$ & 0 & $\mathrm{~L}$ & $\begin{array}{l}\text { Cimahi,04-10- } \\
1995\end{array}$ & $\begin{array}{c}\text { Tidak } \\
\text { diisi }\end{array}$ & 2,6 & 20 & 2,85 & 20 & 2,3 & 20 & 2,8 & 20 & 80 \\
\hline 13 & 131251013 & $\begin{array}{l}\text { Dinidn } \\
\text { Maryadin }\end{array}$ & $\begin{array}{l}\text { S1 Teknik } \\
\text { Mesin }\end{array}$ & Lulus & $\begin{array}{c}\text { Peserta didik } \\
\text { baru }\end{array}$ & 0 & $\mathrm{~L}$ & $\begin{array}{l}\text { Purwakarta,04- } \\
12-1995\end{array}$ & $\begin{array}{c}\text { Tidak } \\
\text { diisi }\end{array}$ & 3 & 20 & 2,95 & 20 & 2,65 & 20 & 2,45 & 20 & 80 \\
\hline 14 & 131251014 & $\begin{array}{l}\text { Endang } \\
\text { Kusnandar }\end{array}$ & $\begin{array}{l}\text { S1 Teknik } \\
\text { Mesin }\end{array}$ & Mutasi & $\begin{array}{c}\text { Peserta didik } \\
\text { baru }\end{array}$ & 0 & $\mathrm{~L}$ & $\begin{array}{l}\text { Purwakarta,03- } \\
02-1995\end{array}$ & $\begin{array}{l}\text { Tidak } \\
\text { diisi }\end{array}$ & 2,35 & 20 & 1,45 & 20 & 0 & 0 & 0 & 0 & 40 \\
\hline 15 & 131251015 & Fajar Alamsyah & $\begin{array}{l}\text { S1 Teknik } \\
\text { Mesin }\end{array}$ & Lulus & $\begin{array}{l}\text { Peserta didik } \\
\text { baru }\end{array}$ & 0 & $\mathrm{~L}$ & $\begin{array}{l}\text { Tangerang,21- } \\
10-1995\end{array}$ & $\begin{array}{c}\text { Tidak } \\
\text { diisi }\end{array}$ & 2,6 & 20 & 2,95 & 20 & 2,35 & 20 & 2,4 & 20 & 80 \\
\hline
\end{tabular}


Penjelasan atribut data dapat dilihat pada table 4.

Tabel 4 Keterangan Atribut

\begin{tabular}{|l|l|l|}
\hline No. & \multicolumn{1}{|c|}{ Atribut } & \multicolumn{1}{c|}{ Keterangan } \\
\hline 1. & NO & Nomor urut data \\
\hline 2. & NIM & Nomor Induk Mahasiswa \\
\hline 3. & NIK & $\begin{array}{l}\text { Nomor Induk } \\
\text { Kependudukan }\end{array}$ \\
\hline 4. & Nama & Nama Mahasiswa \\
\hline 5. & Program Studi & $\begin{array}{l}\text { Program Studi Teknik } \\
\text { Infromatika, Teknik Industri, } \\
\text { Teknik mesin, Menejemen } \\
\text { Industri dan Teknik Tekstil. }\end{array}$ \\
\hline 6. & $\begin{array}{l}\text { Status } \\
\text { Mahasiswa }\end{array}$ & Aktifitas kuliah mahasiswa \\
\hline 7. & $\begin{array}{l}\text { Jenis } \\
\text { Pendaftaran }\end{array}$ & Peserta didik baru / konversi \\
\hline 8. & Biaya Masuk & $\begin{array}{l}\text { Biaya yang dikeluarkan } \\
\text { diawal pendaftaran }\end{array}$ \\
\hline 9. & Jenis Kelamin & Laki-laki dan Perempuan \\
\hline 10. & $\begin{array}{l}\text { Tempat } \\
\text { Tanggal Lahir }\end{array}$ & $\begin{array}{l}\text { Tempat dan Tanggal Lahir } \\
\text { Mahasiswa }\end{array}$ \\
\hline 11. & Agama & Agama Mahasiswa \\
\hline 12. & Alamat & Alamat Mahasiswa \\
\hline 13. & IPS1 & Indek Prestasi Semester 1 \\
\hline 14. & SKS1 & Satuan Kredit Semester 1 \\
\hline 15. & IPS2 & Indek Prestasi Semester 2 \\
\hline 16. & SKS2 & Satuan Kredit Semester 2 \\
\hline 17. & IPS3 & Indek Prestasi Semester 3 \\
\hline 18. & SKS3 & Satuan Kredit Semester 3 \\
\hline 19. & IPS4 & Indek Prestasi Semester 4 \\
\hline 20. & SKS4 & Satuan Kredit Semester 4 \\
\hline 21. & Total SKS & $\begin{array}{l}\text { Total Satuan Kredit } \\
\text { Semester 1-4 }\end{array}$ \\
\hline
\end{tabular}

\section{B. Proses KDD}

Selanjutnya akan dilakukan proses analisis data dengan tahapan sebagai berikut:

\section{Data Selection}

Dari 21 atribut data, yang akan digunakan pada proses klasifikasi ini hanya 6 atribut saja yaitu IPS1, IPS2, IPS3, IPS4, Total SKS dan Status Mahasiswa. Contoh data hasil seleksi yang akan digunakan untuk proses data mining dapat dilihat pada tabel 5 .

Tabel 5 Tabel Data Selection

\begin{tabular}{|l|l|l|l|c|c|}
\hline $\begin{array}{c}\text { IPS } \\
\mathbf{1}\end{array}$ & $\begin{array}{c}\text { IPS } \\
\mathbf{2}\end{array}$ & $\begin{array}{c}\text { IPS } \\
\mathbf{3}\end{array}$ & $\begin{array}{c}\text { IPS } \\
\mathbf{4}\end{array}$ & $\begin{array}{c}\text { Total } \\
\text { SKS }\end{array}$ & $\begin{array}{c}\text { Status } \\
\text { Mahasiswa }\end{array}$ \\
\hline 0 & 0 & 2,6 & 2,55 & 60 & $\begin{array}{c}\text { Mengundurk } \\
\text { an diri }\end{array}$ \\
\hline 2,05 & 2,65 & 2,1 & 0 & 60 & Mutasi \\
\hline 2,75 & 2,9 & 3,25 & 3,25 & 80 & Lulus \\
\hline 2,65 & 0 & 0 & 0 & 20 & Mengundurk \\
\hline
\end{tabular}

\begin{tabular}{|l|l|l|l|c|c|}
\hline $\begin{array}{c}\text { IPS } \\
\mathbf{1}\end{array}$ & $\begin{array}{c}\text { IPS } \\
\mathbf{2}\end{array}$ & $\begin{array}{c}\text { IPS } \\
\mathbf{3}\end{array}$ & $\begin{array}{c}\text { IPS } \\
\mathbf{4}\end{array}$ & $\begin{array}{c}\text { Total } \\
\text { SKS }\end{array}$ & $\begin{array}{c}\text { Status } \\
\text { Mahasiswa }\end{array}$ \\
\hline 2,4 & 2,35 & 1,95 & 1,3 & 80 & Mn diri \\
\hline 2,55 & 3,25 & 2,45 & 1,95 & 80 & Hilang \\
\hline 3 & 3 & 3 & 3,4 & 82 & Lulus \\
\hline 2,05 & 1,15 & 1,8 & 0 & 60 & Hilang \\
\hline 2,5 & 2,95 & 2,8 & 3,3 & 80 & Lulus \\
\hline 2,9 & 3,1 & 3,25 & 3,4 & 80 & Lulus \\
\hline 3,05 & 2,85 & 2,2 & 3 & 80 & $\begin{array}{c}\text { Mengundurk } \\
\text { an diri }\end{array}$ \\
\hline 2,6 & 2,85 & 2,3 & 2,8 & 80 & Lulus \\
\hline 3 & 2,95 & 2,65 & 2,45 & 80 & Lulus \\
\hline 2,35 & 1,45 & 0 & 0 & 40 & Mutasi \\
\hline 2,6 & 2,95 & 2,35 & 2,4 & 80 & Lulus \\
\hline 3,2 & 2,65 & 2,85 & 3,4 & 80 & Lulus \\
\hline 2,65 & 2,85 & 2,25 & 2,05 & 80 & Lulus \\
\hline 2,4 & 0 & 0 & 0 & 20 & Mengundurk \\
\hline 3,2 & 3,2 & 2,85 & 2,65 & 80 & Lulus \\
\hline 3 & 3,15 & 3,25 & 3 & 82 & Lulus \\
\hline & & & & & \\
\hline
\end{tabular}

Tahap selanjutnya, beberapa atribut dilakukan proses klasifikasi data, diantaranya IPS, Total SKS dan Status mahasiswa. Klasifikasi atribut nilai data mahasiswa dapat dilihat pada tabel 6 .

Tabel 6 Klasifikasi Atribut Nilai Data Mahasiswa

\begin{tabular}{|l|c|c|}
\multicolumn{1}{|c|}{ Atribut } & Range & Nilai Atribut \\
\hline IPS1, IPS2, & $0,00-1,30$ & Kurang \\
IPS3, IPS4 & $1,31-2,60$ & Cukup \\
& $2,61-4,00$ & Baik \\
\hline Total SKS & - & $<72$ \\
& & $>=72$ \\
\hline Status & - & Drop out \\
Mahasiswa & & Tidak \\
\hline
\end{tabular}

\section{Prepocessing/cleaning}

Data cleaning merupakan tahap preprocessing yang dilakukan untuk menghapus redudansi data, menghilangkan data mahasiswa konversi, mutasi dan wafat, merubah status mahasiswa mengundurkan diri, hilang, dikeluarkan menjadi Drop out, mengganti status aktif dan lulus menjadi Tidak

\section{Transformasi}

Setelah tahap prepocessing/cleaning, data yang didapat dari dataset bertipe numerik, sedangkan pengujian ini memerlukan data tipe kategori. Teknik 
yang digunakan untuk mengubah data numerik menjadi data kategori selanjutnya akan dilakukan proses transformasi pada dataset,. Contoh data hasil transformasi dapat dilihat pada tabel 7 .

Tabel 7 Data Hasil Transformasi

\begin{tabular}{|c|c|c|c|c|c|}
\hline $\begin{array}{c}\text { IPS } \\
1\end{array}$ & IPS2 & IPS3 & IPS4 & $\begin{array}{c}\text { TOTAL } \\
\text { SKS }\end{array}$ & $\begin{array}{c}\text { Status } \\
\text { Mahasis } \\
\text { wa }\end{array}$ \\
\hline $\begin{array}{c}\text { Cuk } \\
\text { up }\end{array}$ & Baik & Baik & Baik & $>=72$ & Tidak \\
\hline $\begin{array}{l}\text { Cuk } \\
\text { up }\end{array}$ & Baik & Baik & $\begin{array}{c}\text { Cuku } \\
\mathrm{p}\end{array}$ & $>=72$ & $\begin{array}{c}\text { Drop } \\
\text { out }\end{array}$ \\
\hline Baik & Baik & Baik & $\begin{array}{c}\text { Cuku } \\
\mathrm{p}\end{array}$ & $>=72$ & Tidak \\
\hline $\begin{array}{l}\text { Cuk } \\
\text { up }\end{array}$ & $\begin{array}{c}\text { Cuku } \\
\mathrm{p}\end{array}$ & $\begin{array}{c}\text { Cuku } \\
\mathrm{p}\end{array}$ & $\begin{array}{c}\text { Cuku } \\
\mathrm{p}\end{array}$ & $>=72$ & Tidak \\
\hline Baik & Baik & Baik & $\begin{array}{c}\text { Cuku } \\
\mathrm{p}\end{array}$ & $>=72$ & Tidak \\
\hline Baik & Baik & Baik & Baik & $>=72$ & Tidak \\
\hline Baik & Baik & Baik & Baik & $>=72$ & Tidak \\
\hline Baik & Baik & Baik & Baik & $>=72$ & Tidak \\
\hline $\begin{array}{l}\text { Cuk } \\
\text { up }\end{array}$ & Baik & Baik & Baik & $>=72$ & Tidak \\
\hline Baik & Baik & Baik & Baik & $>=72$ & Tidak \\
\hline $\begin{array}{l}\text { Cuk } \\
\text { up }\end{array}$ & Baik & $\begin{array}{c}\text { Cuku } \\
\mathrm{p}\end{array}$ & $\begin{array}{c}\text { Cuku } \\
\mathrm{p}\end{array}$ & $>=72$ & Tidak \\
\hline Baik & Baik & Baik & Baik & $>=72$ & $\begin{array}{c}\text { Drop } \\
\text { out }\end{array}$ \\
\hline Baik & Baik & Baik & Baik & $>=72$ & Tidak \\
\hline Baik & Baik & Baik & Baik & $>=72$ & Tidak \\
\hline Baik & Baik & Baik & Baik & $>=72$ & Tidak \\
\hline Baik & Baik & Baik & Baik & $>=72$ & Tidak \\
\hline Baik & Baik & Baik & Baik & $>=72$ & Tidak \\
\hline $\begin{array}{c}\text { Cuk } \\
\text { up }\end{array}$ & $\begin{array}{c}\text { Kura } \\
\text { ng }\end{array}$ & Baik & Baik & $<72$ & Tidak \\
\hline Baik & Baik & Baik & Baik & $>=72$ & Tidak \\
\hline Baik & Baik & Baik & Baik & $>=72$ & Tidak \\
\hline Baik & $\begin{array}{c}\text { Kura } \\
\text { ng }\end{array}$ & $\begin{array}{c}\text { Kura } \\
\text { ng }\end{array}$ & $\begin{array}{c}\text { Kura } \\
\text { ng }\end{array}$ & $<72$ & $\begin{array}{c}\text { Drop } \\
\text { out }\end{array}$ \\
\hline Baik & $\begin{array}{c}\text { Cuku } \\
\mathrm{p}\end{array}$ & Baik & Baik & $>=72$ & Tidak \\
\hline Baik & Baik & $\begin{array}{c}\text { Kura } \\
\text { ng }\end{array}$ & $\begin{array}{c}\text { Kura } \\
\text { ng }\end{array}$ & $<72$ & $\begin{array}{c}\text { Drop } \\
\text { out }\end{array}$ \\
\hline Baik & Baik & Baik & Baik & $>=72$ & Tidak \\
\hline $\begin{array}{c}\text { Cuk } \\
\text { up }\end{array}$ & Baik & Baik & Baik & $>=72$ & Tidak \\
\hline Baik & Baik & Baik & Baik & $>=72$ & Tidak \\
\hline Baik & Baik & Baik & Baik & $>=72$ & Tidak \\
\hline Baik & Baik & Baik & Baik & $>=72$ & Tidak \\
\hline
\end{tabular}

\begin{tabular}{|c|c|c|c|c|c|}
\hline $\begin{array}{c}\text { IPS } \\
\mathbf{1}\end{array}$ & IPS2 & IPS3 & IPS4 & $\begin{array}{c}\text { TOTAL } \\
\text { SKS }\end{array}$ & $\begin{array}{c}\text { Status } \\
\text { Mahasis } \\
\text { wa }\end{array}$ \\
\hline $\begin{array}{c}\text { Cuk } \\
\text { up }\end{array}$ & $\begin{array}{c}\text { Kura } \\
\text { ng }\end{array}$ & $\begin{array}{c}\text { Kura } \\
\text { ng }\end{array}$ & $\begin{array}{c}\text { Kura } \\
\text { ng }\end{array}$ & $<72$ & $\begin{array}{c}\text { Drop } \\
\text { out }\end{array}$ \\
\hline $\begin{array}{c}\text { Cuk } \\
\text { up }\end{array}$ & $\begin{array}{c}\text { Cuku } \\
\text { p }\end{array}$ & Baik & $\begin{array}{c}\text { Cuku } \\
\text { p }\end{array}$ & $>=72$ & $\begin{array}{c}\text { Drop } \\
\text { out }\end{array}$ \\
\hline $\begin{array}{c}\text { Cuk } \\
\text { up }\end{array}$ & Baik & Baik & Baik & $>=72$ & Tidak \\
\hline Baik & Baik & Baik & Baik & $>=72$ & Tidak \\
\hline
\end{tabular}

Setelah dilakukan transformasi, selanjutnya data dapat diolah di aplikasi Orange sehingga dapat menghasilkan rule klasifikasi data.

\section{Pemodelan Data Mining dengan aplikasi Orange}

1. Siapkan dataset

Pada penelitian ini digunakan 467 data mahasiswa STT Wastukancana angkatan 2013 sebagai data training dan 577 data mahasiswa STT Wastukancana angkatan 2017 sebagai data testing untuk melakukan prediksi. Setelah proses pengumpulan data, seleksi data, cleaning dan transformasi maka data siap untuk diolah dengan menggunakan aplikasi orange. gambar 4.2 menunjukkan dataset training yang telah diupload ke aplikasi Orange.

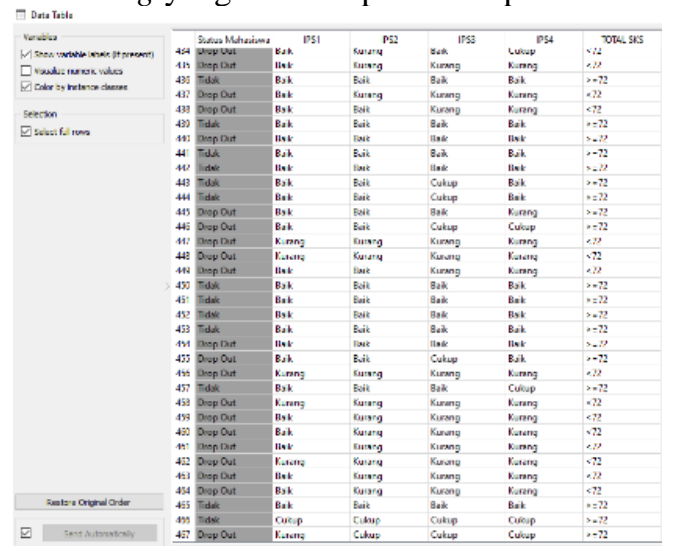

Gambar 2 Dataset Training

Gambar 3 menunjukkan dataset testing yang akan dijadikan bahan untuk memprediksi mahasiswa Drop out.

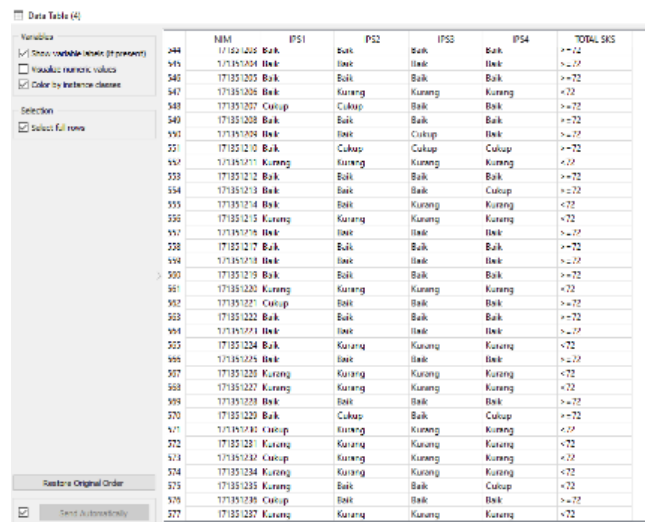

Gambar 3 Data Testing 
2. Membuat Pemodelan

Setelah data diupload, selanjutnya dilakukan pemodelan seperti yang terlihat pada gambar 4 .

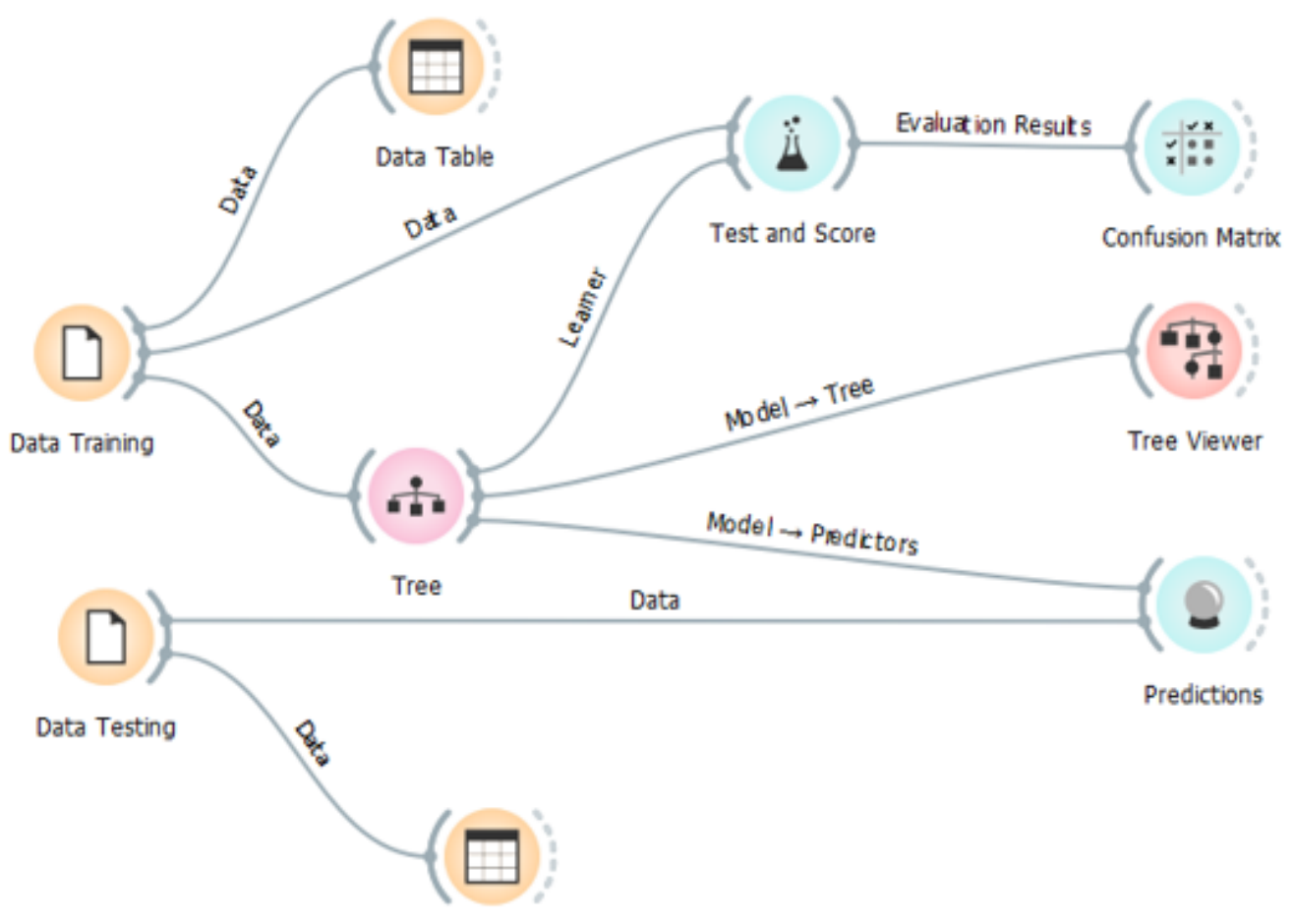

Data Table (4)

Gambar 4 Pemodelan Menggunakan Aplikasi Orange

Berikut penjelasan pemodelan yang digunakan:

a. Data Training

Data training merupakan dataset yang terdiri dari 467 mahasiswa angkatan 2013.

b. Data Testing

Data testing merupakan dataset yang terdiri dari 577 mahasiswa angkatan 2017.

c. Data Table

Data table berfungsi untuk menampilkan data yang telah diupload ke aplikasi.

d. Tree

Tree merupakan model yang digunakan pada penelitian ini (Decision Tree Algoritma ID3)

e. Tree Viewer

Tree Viewer berfungsi untuk menampilakn tree yang terbentuk dari hasil pengolahan data.

f. Prediction

Prediction berfungsi untuk menampilkan hasil prediksi dari pengolahan 577 data mahasiswa angkatan 2017 , berdasarkan rules yang dihasilkan oleh perhitungan dari 467 data.

g. Test and Score dan Confusion Matrix berfungsi untuk mengevaluasi hasil pemodelan Decision Tree. 


\section{Proses Pembentukan Decision Tree}

Gambar 5 menujukkan Decision tree hasil pengolahan data menggunakan aplikasi orange.

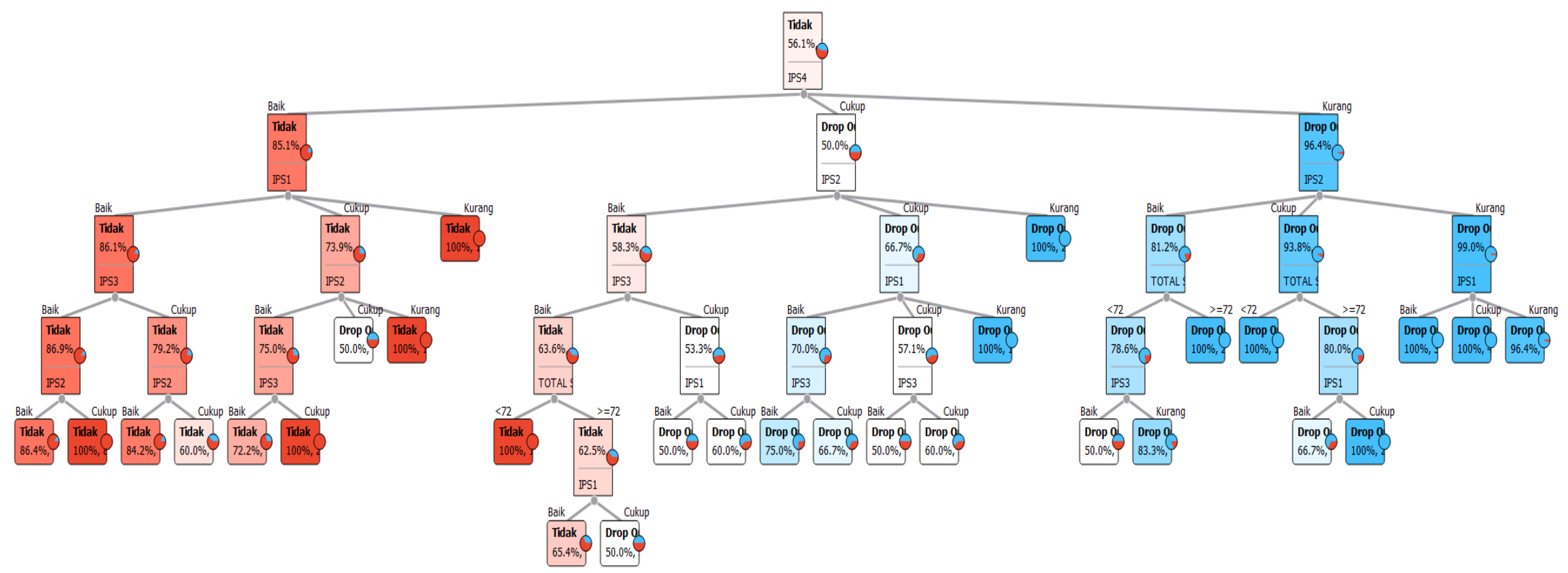

Gambar 5 Decision Tree 
Proses pengolahan data menghasilkan rules sebagai berikut:

\section{Tree}

1. IPS4 $=$ Baik, IPS1 $=$ Baik, IPS3 $=$ Baik, IPS2 $=$ Baik, : 86,4\% Tidak \{ \}

2. IPS4 $=$ Baik, IPS1 $=$ Baik, IPS3 $=$ Baik, IPS2 $=$ Cukup, : 100\% Tidak \{ \}

3. IPS4 $=$ Baik, IPS1 $=$ Baik, IPS3 = Cukup, IPS2 = Baik, : 84,2\% Tidak \{ \}

4. IPS $4=$ Baik, IPS $1=$ Baik, IPS $3=$ Cukup, IPS2 = Cukup, : 60\% Tidak \{ \}

5. IPS4 $=$ Baik, IPS $1=$ Cukup, IPS2 $=$ Baik, IPS3 $=$ Baik, : 72,2\% Tidak \{ \}

6. IPS4 $=$ Baik, IPS1 $=$ Cukup, IPS2 $=$ Baik, IPS3 $=$ Cukup, : 100\% Tidak \{ \}

7. IPS $4=$ Baik, IPS $1=$ Cukup, IPS $2=$ Cukup, $: 50 \%$ Drop out \{\}

8. IPS4 = Baik, IPS1 = Cukup, IPS2 = Kurang, 100\% Tidak \{ \}

9. IPS4 $=$ Baik, IPS $1=$ Kurang, : $100 \%$ Tidak \{\}

10. IPS $4=$ Cukup, IPS $2=$ Baik, IPS3 = Baik, Total Kasus $=<72: 100 \%$ Tidak \{\}

11. IPS $4=$ Cukup, IPS $2=$ Baik, IPS $3=$ Baik, Total Kasus $=>=72$, IPS $1=$ Baik, $: 65,4 \%$ Tidak \{\}

12. IPS $4=$ Cukup, IPS $2=$ Baik, IPS $3=$ Baik, Total Kasus $=>=72$, IPS $1=$ Cukup, : $50 \%$ Drop out \{ \}

13. IPS $4=$ Cukup, IPS $2=$ Baik, IPS $3=$ Cukup, IPS 1 $=$ Baik, : $50 \%$ Drop out \{\}

14. IPS4 $=$ Cukup, IPS $2=$ Baik, IPS3 = Baik, IPS $1=$ Cukup, : $60 \%$ Drop out \{\}

15. IPS $4=$ Cukup, IPS $2=$ Cukup, IPS $1=$ Baik, IPS 3 $=$ Baik, : $75 \%$ Drop out \{\}

16. IPS $4=$ Cukup, IPS $2=$ Cukup, IPS $1=$ Baik, IPS 3 = Cukup, $: 66,7 \%$ Drop out \{\}

17. IPS4 $=$ Cukup, IPS $2=$ Cukup, IPS $1=$ Cukup, IPS3 = Baik, : $50 \%$ Drop out \{\}

18. IPS4 $=$ Cukup, IPS2 $=$ Cukup, IPS $1=$ Cukup, IPS3 = Cukup, : 60\% Drop out \{\}

19. IPS $4=$ Cukup, IPS $2=$ Cukup, IPS $1=$ Kurang, : $100 \%$ Drop out \{\}

20. IPS4 = Cukup, IPS2 = Kurang, : $100 \%$ Drop out \{ \}

21. IPS $4=$ Kurang, IPS $2=$ Baik, Total Kasus $=<72$, IPS3 = Baik, : $50 \%$ Drop out \{\}

22. IPS $4=$ Kurang, IPS $2=$ Baik, Total Kasus $=<72$, IPS3 = Kurang, : 83,3\% Drop out \{\}

23. IPS $4=$ Kurang, IPS $2=$ Baik, Total Kasus $=>=72$, : $100 \%$ Drop out \{\}

24. IPS4 $=$ Kurang, IPS $2=$ Cukup, Total Kasus $=<72$, : 100\% Drop out \{\}

25. IPS $4=$ Kurang, IPS $2=$ Cukup, Total Kasus $=$ $>=72$, IPS1 = Baik : 66,7\% Drop out \{\}

26. IPS4 $=$ Kurang, IPS $2=$ Cukup, Total Kasus $=$ $>=72$, IPS $1=$ Cukup : $100 \%$ Drop out \{\}

27. IPS $4=$ Kurang, IPS $2=$ Kurang, IPS $1=$ Baik : $100 \%$ Drop out $\{$ \}
28. IPS $4=$ Kurang, IPS $2=$ Kurang, IPS $1=$ Cukup: $100 \%$ Drop out \{\}

29. IPS4 = Kurang, IPS2 = Kurang, IPS1 = Baik : 96,4\% Drop out \{\}

Berdasarkan rules yang terbentuk, dapat diketahui bahwa mahasiswa berpotensi Drop out adalah mahasiswa dengan:

1. IPS4 $=$ Baik, IPS $1=$ Cukup, IPS $2=$ Cukup, $: 50 \%$ Drop out \{\}

2. IPS $4=$ Cukup, IPS $2=$ Baik, IPS $3=$ Baik, Total Kasus $=>=72$, IPS $1=$ Cukup, : $50 \%$ Drop out \{ \}

3. IPS $4=$ Cukup, IPS $2=$ Baik, IPS $3=$ Cukup, IPS 1 = Baik, : 50\% Drop out \{\}

4. IPS4 $=$ Cukup, IPS2 $=$ Baik, IPS3 $=$ Baik, IPS1 $=$ Cukup, : 60\% Drop out \{\}

5. IPS4 $=$ Cukup, IPS2 $=$ Cukup, IPS $1=$ Baik, IPS3 = Baik, : 75\% Drop out \{\}

6. IPS4 $=$ Cukup, IPS $2=$ Cukup, IPS $1=$ Baik, IPS3 = Cukup, : 66,7\% Drop out \{\}

7. IPS4 $=$ Cukup, IPS $2=$ Cukup, IPS $1=$ Cukup, IPS3 = Baik, : 50\% Drop out \{\}

8. IPS4 $=$ Cukup, IPS $2=$ Cukup, IPS1 $1=$ Cukup, IPS3 = Cukup, : 60\% Drop out \{\}

9. IPS4 $=$ Cukup, IPS2 $=$ Cukup, IPS1 $=$ Kurang, : $100 \%$ Drop out \{\}

10. IPS $4=$ Cukup, IPS $2=$ Kurang, $: 100 \%$ Drop out \{ \}

11. IPS $4=$ Kurang, IPS $2=$ Baik, Total Kasus $=<72$, IPS3 = Baik, : 50\% Drop out \{\}

12. IPS $4=$ Kurang, IPS $2=$ Baik, Total Kasus $=<72$, IPS3 = Kurang, : 83,3\% Drop out \{\}

13. IPS $4=$ Kurang, IPS $2=$ Baik, Total Kasus $=>=72$, : $100 \%$ Drop out \{\}

14. IPS $4=$ Kurang, IPS $2=$ Cukup, Total Kasus $=<72$, : $100 \%$ Drop out \{\}

15. IPS4 $=$ Kurang, IPS $2=$ Cukup, Total Kasus $=$ $>=72$, IPS $1=$ Baik $: 66,7 \%$ Drop out \{\}

16. IPS $4=$ Kurang, IPS $2=$ Cukup, Total Kasus $=$ $>=72$, IPS $1=$ Cukup : $100 \%$ Drop out \{\}

17. IPS $4=$ Kurang, IPS $2=$ Kurang, IPS $1=$ Baik : 100\% Drop out \{\}

18. IPS4 = Kurang, IPS $2=$ Kurang, IPS $1=$ Cukup: $100 \%$ Drop out \{\}

19. IPS4 $=$ Kurang, IPS $2=$ Kurang, IPS $1=$ Baik : 96,4\% Drop out \{\}

Setelah dilakukan proses pemodelan, selanjutnya akan dilakukan proses evaluasi untuk membuktikan keakuratan terhadap tree yang terbentuk. 

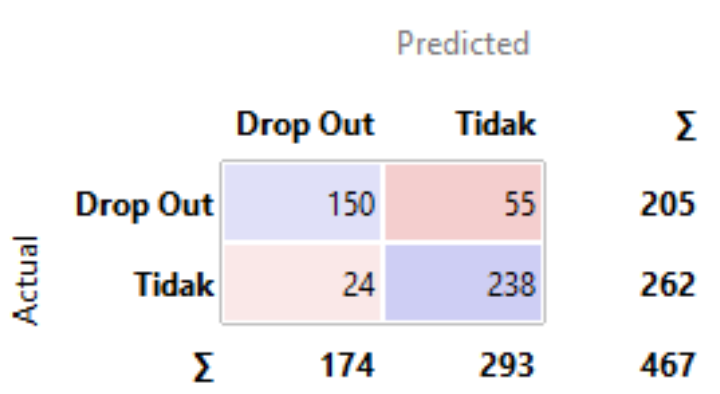

\section{Gambar 6 Confussion Matrix}

Hasil evaluasi dengan menggunakan confusion matrix menunjukan bahwa:

1. Jumlah actual Drop out, predicted Drop out sebanyak 150 data

2. Jumlah actual Drop out, predicted Tidak sebanyak 55 data

3. Jumlah actual Tidak, predicted Drop out sebanyak 24 data

4. Jumlah actual Tidak, predicted Tidak sebanyak 238 data

Nilai akurasi dari perhitungannya adalah:

$$
\begin{aligned}
& \text { 1. Akurasi }=\frac{\mathrm{TP}+\mathrm{TN}}{\mathrm{TP}+\mathrm{TN}+\mathrm{FP}+\mathrm{FN}} \times 100 \% \\
& =\frac{150+238}{150+238+55+24} \times 100 \% \\
& =83,1 \%
\end{aligned}
$$

2. Presisi $=\frac{\mathrm{TP}}{\mathrm{TP}+\mathrm{FP}} \times 100 \%$

$$
\begin{aligned}
& =\frac{150}{150+24} \times 100 \% \\
& =86,2 \%
\end{aligned}
$$

3. Recall $=\frac{\mathrm{TP}}{\mathrm{TP}+\mathrm{FN}} \times 100 \%$

$$
\begin{aligned}
& =\frac{150}{150+55} \times 100 \% \\
& =73,2 \%
\end{aligned}
$$

\section{Analisis Prediksi Data}

Setelah dilakukan pembentukan Tree, selanjutnya akan dilakukan proses prediksi data mahasiswa angkatan 2017 sebanyak 577. Pada proses ini dianalisa

\begin{tabular}{|c|c|c|c|c|c|c|c|}
\hline NIM & Nama & $\begin{array}{c}\text { IPS } \\
1\end{array}$ & $\begin{array}{c}\text { IPS } \\
2\end{array}$ & $\begin{array}{c}\text { IPS } \\
\mathbf{3}\end{array}$ & $\begin{array}{c}\text { IPS } \\
4\end{array}$ & $\begin{array}{c}\text { TOT } \\
\text { AL } \\
\text { SKS }\end{array}$ & $\begin{array}{c}\text { Pred } \\
\text { iksi }\end{array}$ \\
\hline & na & & & & & & \\
\hline $\begin{array}{c}17115 \\
1003\end{array}$ & $\begin{array}{l}\text { Adam } \\
\text { Sundan } \\
\text { a }\end{array}$ & $\begin{array}{l}\text { Kur } \\
\text { ang }\end{array}$ & $\begin{array}{l}\text { Kur } \\
\text { ang }\end{array}$ & $\begin{array}{l}\text { Kur } \\
\text { ang }\end{array}$ & $\begin{array}{l}\text { Kur } \\
\text { ang }\end{array}$ & $<72$ & $\begin{array}{c}\text { Drop } \\
\text { out }\end{array}$ \\
\hline $\begin{array}{c}17115 \\
1004\end{array}$ & $\begin{array}{l}\text { Adi } \\
\text { Sumarn } \\
\text { a }\end{array}$ & $\begin{array}{l}\text { Kur } \\
\text { ang }\end{array}$ & $\begin{array}{l}\text { Kur } \\
\text { ang }\end{array}$ & $\begin{array}{c}\text { Cuk } \\
\text { up }\end{array}$ & $\begin{array}{c}\text { Cuk } \\
\text { up }\end{array}$ & $>=72$ & $\begin{array}{c}\text { Drop } \\
\text { out }\end{array}$ \\
\hline $\begin{array}{c}17115 \\
1005\end{array}$ & $\begin{array}{l}\text { Adli } \\
\text { Handik } \\
\text { a }\end{array}$ & $\begin{array}{l}\text { Kur } \\
\text { ang }\end{array}$ & $\begin{array}{l}\text { Kur } \\
\text { ang }\end{array}$ & $\begin{array}{l}\text { Kur } \\
\text { ang }\end{array}$ & $\begin{array}{l}\text { Kur } \\
\text { ang }\end{array}$ & $<72$ & $\begin{array}{c}\text { Drop } \\
\text { out }\end{array}$ \\
\hline $\begin{array}{c}17115 \\
1006\end{array}$ & $\begin{array}{l}\text { Adrian } \\
\text { Pratam } \\
\text { a }\end{array}$ & $\begin{array}{l}\text { Kur } \\
\text { ang }\end{array}$ & $\begin{array}{l}\text { Kur } \\
\text { ang }\end{array}$ & $\begin{array}{c}\text { Cuk } \\
\text { up }\end{array}$ & $\begin{array}{l}\text { Kur } \\
\text { ang }\end{array}$ & $>=72$ & $\begin{array}{c}\text { Drop } \\
\text { out }\end{array}$ \\
\hline $\begin{array}{c}17115 \\
1007\end{array}$ & $\begin{array}{l}\text { Adytio } \\
\text { Handia } \\
\text { nto }\end{array}$ & $\begin{array}{l}\text { Kur } \\
\text { ang }\end{array}$ & $\begin{array}{l}\text { Kur } \\
\text { ang }\end{array}$ & $\begin{array}{c}\text { Cuk } \\
\text { up }\end{array}$ & $\begin{array}{l}\text { Cuk } \\
\text { up }\end{array}$ & $>=72$ & $\begin{array}{c}\text { Drop } \\
\text { out }\end{array}$ \\
\hline $\begin{array}{c}17115 \\
1008\end{array}$ & $\begin{array}{l}\text { Afifah } \\
\text { Nuraini }\end{array}$ & $\begin{array}{l}\text { Kur } \\
\text { ang }\end{array}$ & $\begin{array}{l}\text { Kur } \\
\text { ang }\end{array}$ & Baik & Baik & $>=72$ & $\begin{array}{c}\text { Tida } \\
\mathrm{k}\end{array}$ \\
\hline $\begin{array}{c}17115 \\
1009\end{array}$ & $\begin{array}{l}\text { Afrizal } \\
\text { yuriz } \\
\text { Ruhiat } \\
\text { Nurfird } \\
\text { aus }\end{array}$ & $\begin{array}{l}\text { Kur } \\
\text { ang }\end{array}$ & $\begin{array}{l}\text { Kur } \\
\text { ang }\end{array}$ & Baik & Baik & $>=72$ & $\begin{array}{c}\text { Tida } \\
\mathrm{k}\end{array}$ \\
\hline $\begin{array}{c}17115 \\
1010\end{array}$ & $\begin{array}{l}\text { Agung } \\
\text { Gumel } \\
\text { ar }\end{array}$ & $\begin{array}{l}\text { Kur } \\
\text { ang }\end{array}$ & $\begin{array}{l}\text { Kur } \\
\text { ang }\end{array}$ & Baik & Baik & $>=72$ & $\begin{array}{c}\text { Tida } \\
\text { k }\end{array}$ \\
\hline $\begin{array}{c}17115 \\
1011\end{array}$ & $\begin{array}{l}\text { Agus } \\
\text { Ahmad } \\
\text { Kosim }\end{array}$ & $\begin{array}{l}\text { Kur } \\
\text { ang }\end{array}$ & $\begin{array}{l}\text { Kur } \\
\text { ang }\end{array}$ & Baik & Baik & $>=72$ & $\begin{array}{c}\text { Tida } \\
\mathrm{k}\end{array}$ \\
\hline $\begin{array}{c}17115 \\
1012 \\
\end{array}$ & $\begin{array}{l}\text { Ahmad } \\
\text { Yusup }\end{array}$ & $\begin{array}{l}\text { Kur } \\
\text { ang }\end{array}$ & $\begin{array}{l}\text { Kur } \\
\text { ang }\end{array}$ & Baik & Baik & $>=72$ & $\begin{array}{c}\text { Tida } \\
\mathrm{k}\end{array}$ \\
\hline $\begin{array}{c}17115 \\
1013\end{array}$ & $\begin{array}{l}\text { Aji } \\
\text { Maulud } \\
\text { i }\end{array}$ & $\begin{array}{l}\text { Kur } \\
\text { ang }\end{array}$ & $\begin{array}{l}\text { Kur } \\
\text { ang }\end{array}$ & $\begin{array}{l}\text { Cuk } \\
\text { up }\end{array}$ & $\begin{array}{c}\text { Cuk } \\
\text { up }\end{array}$ & $>=72$ & $\begin{array}{c}\text { Drop } \\
\text { out }\end{array}$ \\
\hline $\begin{array}{c}17115 \\
1014\end{array}$ & $\begin{array}{l}\text { Aji } \\
\text { Prasety } \\
\text { o }\end{array}$ & $\begin{array}{l}\text { Kur } \\
\text { ang }\end{array}$ & $\begin{array}{l}\text { Kur } \\
\text { ang }\end{array}$ & Baik & Baik & $>=72$ & $\begin{array}{c}\text { Tida } \\
\mathrm{k}\end{array}$ \\
\hline $\begin{array}{c}17115 \\
1015\end{array}$ & $\begin{array}{l}\text { Aldi } \\
\text { Septian } \\
\text { to }\end{array}$ & $\begin{array}{l}\text { Kur } \\
\text { ang }\end{array}$ & $\begin{array}{l}\text { Kur } \\
\text { ang }\end{array}$ & $\begin{array}{c}\text { Cuk } \\
\text { up }\end{array}$ & $\begin{array}{l}\text { Kur } \\
\text { ang }\end{array}$ & $<72$ & $\begin{array}{c}\text { Drop } \\
\text { out }\end{array}$ \\
\hline $\begin{array}{c}17115 \\
1016\end{array}$ & $\begin{array}{l}\text { Aldian } \\
\text { Yusuf } \\
\text { Gunaw } \\
\text { an }\end{array}$ & $\begin{array}{l}\text { Kur } \\
\text { ang }\end{array}$ & $\begin{array}{l}\text { Kur } \\
\text { ang }\end{array}$ & $\begin{array}{l}\text { Cuk } \\
\text { up }\end{array}$ & Baik & $>=72$ & $\begin{array}{c}\text { Tida } \\
\mathrm{k}\end{array}$ \\
\hline $\begin{array}{c}17115 \\
1017\end{array}$ & $\begin{array}{l}\text { Alin } \\
\text { Asry } \\
\text { Nugrah } \\
\text { a }\end{array}$ & $\begin{array}{l}\text { Kur } \\
\text { ang }\end{array}$ & $\begin{array}{l}\text { Kur } \\
\text { ang }\end{array}$ & Baik & Baik & $>=72$ & $\begin{array}{c}\text { Tida } \\
\mathrm{k}\end{array}$ \\
\hline $\begin{array}{c}17115 \\
1018 \\
\end{array}$ & $\begin{array}{l}\text { Andi } \\
\text { Adryan }\end{array}$ & $\begin{array}{l}\text { Kur } \\
\text { ang }\end{array}$ & $\begin{array}{l}\text { Kur } \\
\text { ang }\end{array}$ & Baik & $\begin{array}{l}\text { Kur } \\
\text { ang }\end{array}$ & $<72$ & $\begin{array}{c}\text { Drop } \\
\text { out }\end{array}$ \\
\hline $\begin{array}{c}17115 \\
1019\end{array}$ & $\begin{array}{l}\text { Andi } \\
\text { Sophia } \\
\text { n }\end{array}$ & $\begin{array}{l}\text { Kur } \\
\text { ang }\end{array}$ & $\begin{array}{l}\text { Kur } \\
\text { ang }\end{array}$ & $\begin{array}{l}\text { Kur } \\
\text { ang }\end{array}$ & $\begin{array}{l}\text { Kur } \\
\text { ang }\end{array}$ & $<72$ & $\begin{array}{c}\text { Drop } \\
\text { out }\end{array}$ \\
\hline
\end{tabular}
apakah hasil prediksi sesuai dengan rules yang terbentuk pada Decision Tree. Dataset hasil prediksi dapat dilihat pada table 7 .

Tabel 2 Dataset Hasil Prediksi

\begin{tabular}{|c|l|c|c|c|c|c|c|}
\hline NIM & Nama & $\begin{array}{c}\text { IPS } \\
\mathbf{1}\end{array}$ & $\begin{array}{c}\text { IPS } \\
\mathbf{2}\end{array}$ & $\begin{array}{c}\text { IPS } \\
\mathbf{3}\end{array}$ & $\begin{array}{c}\text { IPS } \\
\mathbf{4}\end{array}$ & $\begin{array}{c}\text { TOT } \\
\text { AL } \\
\text { SKS }\end{array}$ & $\begin{array}{c}\text { Pred } \\
\text { iksi }\end{array}$ \\
\hline $\begin{array}{c}17115 \\
1001\end{array}$ & $\begin{array}{l}\text { Abizar } \\
\text { Al- } \\
\text { Afkar } \\
\text { Fauzan }\end{array}$ & $\begin{array}{c}\text { Kur } \\
\text { ang }\end{array}$ & $\begin{array}{c}\text { Kur } \\
\text { ang }\end{array}$ & Baik & $\begin{array}{c}\text { Kur } \\
\text { ang }\end{array}$ & $>=72$ & $\begin{array}{c}\text { Drop } \\
\text { out }\end{array}$ \\
\hline $\begin{array}{c}17115 \\
1002\end{array}$ & $\begin{array}{l}\text { Acep } \\
\text { Restu } \\
\text { Rusma }\end{array}$ & $\begin{array}{c}\text { Kur } \\
\text { ang }\end{array}$ & $\begin{array}{c}\text { Kur } \\
\text { ang }\end{array}$ & $\begin{array}{c}\text { Cuk } \\
\text { up }\end{array}$ & $\begin{array}{c}\text { Kur } \\
\text { ang }\end{array}$ & $>=72$ & $\begin{array}{c}\text { Drop } \\
\text { out }\end{array}$ \\
\hline
\end{tabular}

Berdasarkan hasil prediksi 577 data, dapat diketahui bahwa jumlah mahasiswa berpotensi Drop out sebanyak 281 orang dan mahasiswa yang tidak berpotensi Drop out sebanyak 296 orang. Bagi mahasiswa yang diprediksi Drop out, selanjutnya dilakukan bimbingan khusus untuk menghindari kemungkinan Drop out terjadi.

E. Evaluasi 
Berdasarkan hasil pengolahan data mining, dapat dilakukan perbaikan-perbaikan strategi untuk mengurangi jumlah mahasiswa berpotensi Drop out di STT Wastukancana, diantaranya:

1. Melakukan prediksi data mahasiswa setiap angkatan, sehingga dapat diketahui apakah mahasiswa tersebut akan menyelesaikan pendidikan hingga lulus atau akan berpotensi Drop out.

2. Menambah fitur prediksi pada sistem informasi akademik, dimana dosen wali dan mahasiswa dapat melihat grafik perkembangan akademik mahasiswa. Sehingga bagi mahasiswa yang diprediksi Drop out akan diberikan pembinaan untuk menghindari potensi tersebut.

\section{KESIMPULAN}

Berdasarkan hasil penelitian yang dilakukan terhadap 467 data mahasiswa angkatan 2013, konstruksi Pohon Keputusan (Decision tree) yang terbentuk dengan menggunakan Algoritma ID3 menghasilkan pohon sebanyak 50 simpul dengan IPS4 terpilih sebagai akarnya. Pengukuran kinerja klasifikasi menunjukkan bahwa akurasi mencapai $83,1 \%$, precision $86,2 \%$ dan recall sebesar $73,2 \%$. Sedangkan berdasarkan hasil prediksi dari 577 data mahasiswa angkatan 2017, dapat diketahui bahwa jumlah mahasiswa berpotensi Drop out sebanyak 281 orang dan mahasiswa yang tidak berpotensi Drop out sebanyak 296 orang. Hasil dari prediksi data ini dapat dijadikan salah satu bahan untuk meminimalisir potensi mahasiswa Drop out di STT Wastukancana.

Saran untuk penelitian ini yaitu dapat dilakukan penelitian lain dengan menggunakan algoritma yang berbeda seperti algoritma Naïve Bayes. Sehingga diharapkan nilai akurasinya akan semakin baik. Selain itu, atribut yang digunakan pada perhitungan dapat ditambah seperti jumlah penghasilan, tempat tinggal dan latar belakang sekolah, sehingga prediksi akan semakin bervariasi tidak hanya dari segi akademik, tapi juga dari segi ekonomi dan sosial.

\section{DAFTAR PUSTAKA}

[1] D. A. Yosepta and Tria Aprilianto, "Analisa Pola Kelulusan Mahasiswa Pada Sekolah Tinggi Manajemen Informatika \& Komputer Asia Malang Dengan Menggunakan algoritma Iterative Dichotomiser 3 (ID3)," Positif, vol. 3, no. 1, pp. 47-55, 2017.

[2] K. Hastuti and E. Y. Hidayat, "Analisis Algoritma Decision Tree untuk Prediksi Mahasiswa Non Aktif," Semantik, vol. 2013, no. November, pp. 211-216, 2013.

[3] STT Wastukancana, Buku Panduan Akademik. Purwakarta, 2014.

[4] D. K. Widiyati, M. Wati, and H. S. Pakpahan,
"Penerapan Algoritma ID3 Decision Tree Pada Penentuan Penerima Program Bantuan Pemerintah Daerah di Kabupaten Kutai Kartanegara," J. Rekayasa Teknol. Inf., vol. 2, no. 2, p. 125, 2018, doi: 10.30872/jurti.v2i2.1864.

[5] I. Srimenganti, I. Taufik, and E. Mulyana, "Implementasi Algoritma Decision Tree ( ID3 ) Untuk Penyakit Campak," Semin. Nas. Tek. Elektro, pp. 235-242, 2018.

[6] T. Thi Bi Dan, S. Widya Sihwi, and R. Anggrainingsih, "Implementasi Iterative Dichotomiser 3 Pada Data Kelulusan Mahasiswa S1 Di Universitas Sebelas Maret," J. Teknol. Inf. ITSmart, vol. 4, no. 2, p. 84, 2016, doi: 10.20961/its.v4i2.1770.

[7] A. E. Tyasti, D. Ispriyanti, and A. Hoyyi, "Algoritma Iterative Dichotomiser 3 (ID3) untuk Mengidentifikasi Data Rekam Medis," Gaussian, vol. 4, no. Dm, pp. 237-246, 2015.

[8] T. D. Utama, S. W. Sihwi, and A. Doewes, "Implementasi Algoritma Iterative Dichotomiser 3 Pada Penyeleksian Program Mahasiswa Wirausaha Uns," J. Itsmart, vol. 3, no. 2, pp. 74-82, 2014.

[9] Dwi Untari, "Data Mining untuk Menganalisa Prediksi Mahasiswa Berpotensi Non-Aktif Menggunaka Metode Decision Tree C4.5," Fak. Ilmu Komput. Univ. Dian Nuswantoro, 2010.

[10] F. Pratiwi, "SATIN - Sains dan Teknologi Informasi Analisa Pemilihan Bahasa Pemograman dalam Penyelesaian Tugas Akhir Mahasiswa," vol. 4, no. 2, 2018.

[11] Triase dan Samsudin, "Implementasi Data Mining Dalam Mengklasifikasikan Ukt ( Uang Kuliah Tunggal ) Pada Uin Sumatera Utara Medan," J. Teknol. Inf. Jurti, vol. 4, no. 2, pp. 370-376, 2020. 